\section{Blood Clotting System in the Pathogenesis of the Sanarelli-Shwartzman Reaction of the Rabbit}

The generalized Shwartzman reaction is elicited in rabbits by means of two intravenous injections of endotoxin of Gram-negative bacteria given $24 \mathrm{~h}$ apart. Renal cortical necrosis is pathognomonic ${ }^{1}$. The demonstration of intravascular thrombin-activity ${ }^{2,3}$ in rabbits treated in this way raised the question whether the thrombin alone can be made responsible for the morphological substratum characterizing this phenomenon. In order to clarify the importance played by the clotting mechanisms in the pathogenesis of the generalized Shwartzman reaction, the following studies were performed.

New Zealand rabbits weighing $2-2.5 \mathrm{~kg}$ were catheterized as described previously 4 . Resin thrombin (chromatographed and free of autoprothrombin-C) was prepared from purified bovine prothrombin ${ }^{5}$. $E$. coli endotoxin and Thorotrast were generously supplied by Testagar Laboratories, Detroit (Michigan). The doses used were: Thrombin-infusion: $400 \mathrm{U}$ infused continuously for $4 \mathrm{~h}$ by intracardiac catheterization. Endotoxin: 'preparative' dose $200 \gamma$, 'provocative' dose $2000 \gamma$. Thorotrast $3 \mathrm{~cm}^{3} / \mathrm{kg}$ of corporal weight.

The following experiments were carried out: Group 1, $2 \mathrm{i}, \mathrm{v}$. doses of endotoxin ('preparative' and 'provocative' doses $24 \mathrm{~h}$ apart). Five animals : all animals developed the characteristic renal cortical necrosis. Group 2, preparation with Thorotrast. Provocative endotoxin injection $24 \mathrm{~h}$ later. Five animals: all five rabbits showed renal cortical necrosis. Group 3, single endotoxin injection. Five animals: no renal cortical necrosis observed. Group 4, single thrombin infusion: none of the five experimental animals developed cortical necrosis of the kidney. Group 5, double thrombin infusion, $24 \mathrm{~h}$ apart. None of the five animals showed the bilateral cortical necrosis. Group 6 , preparation with thrombin infusion and provocation with endotoxin. Five animals, all developed renal cortical necrosis. Group 7, preparation with endotoxin, provocation with thrombin infusion. Five animals: no renal cortical necrosis in the necropsy, $48 \mathrm{~h}$ after the thrombin infusion.

The above experiments show that the bilateral renal cortical necrosis can only be seen in experiments having endotoxin as 'provocative' injection. Thrombin in the dose used has 'preparative' but not 'provocative' properties.

It is concluded from these experiments, that the blood clotting mechanism has to be activated as conditio sine qua non in order to produce the generalized Shwartzman reaction. However, the endotoxin itself enhances effects other than the activation of the coagulation system, which are demonstrated to be essential. These are thought to be mainly vasculodynamic in character ${ }^{\circ}$. Pari passu with both endotoxin effects, the reticulo-endothelial system has to be impaired in its phagocytic function? in order to fulfil all requirements for the production of the reaction.

Zusammenfassung. Chromatographiertes, Autoprothrombin-C-freies Thrombin wurde Versuchstieren allein bzw. in Verbindung mit Endotoxin oder nach Blockierung des RES mittels Thorotrast, infundiert. Die Ergebnisse zeigen, dass das Thrombin in der angegebenen Dosierung vorbereitende, nicht aber auslösende Eigenschaften besitzt.

\section{F. RODRIGUEZ-ERDMANN ${ }^{8}$}

Department of Physiology and Pharmacology, Wayne

State University School of Medicine, Detroit (Mich.,

U.S.A.), December 9, 1963.

1 L. Thomas, in Rheumatic Feuer, a Symposium (University of Minnesota Press, Minneapolis 1952), p. 232.

2 F. Rodrfguez-Erdmans and H. G. Lasch, Proc, 8th Congress Europ. Soc. Haemat. Vienna 1061, Nr, 468 (S. Karger, Basel-New York 1962).

a. Rodríguez-ERDManN, in press.

4 F. Rodríguez-Erdmann, Pflügers Archiv ges. Physiol. 269, 306 (1959).

5 W. H. SeEgers, W. G. Levine, and R. S. Shepard, Canad. J. Biochem. Physiol, 36, 603 (1958).

- F. Rodríguez-Erdman, in press.

7 L. Thomas, in Physiopathology of the Reticulo-endothelial System (Blackwell, Oxford 1957), p. 226.

8 Present adress: Department of Haematology, Tufts-New England Medical Center, Boston (Mass., U.S.A.).

\section{Metabolism of Diphenylamine in the Rat and Rabbit $^{1}$}

Diphenylamine is an effective agent for the prevention of superficial scald in apples and other fruits. The toxic effect of aromatic amines and the carcinogenic properties of certain hydroxylated and $\mathrm{N}$-hydroxylated aromatic amines ${ }^{2,3}$ are well known, and because of this, we have examined the metabolism of this substance in the rat and rabbit.

The urine of rats given $5 \mathrm{mg}$ intraperitoneal doses of diphenylamine or 4-hydroxydiphenylamine or N-hydroxydiphenylamine ${ }^{4}$ was found to contain a conjugate as the major metabolite which gave 4-hydroxydiphenylamine on hydrolysis with hydrochloric acid or enzymatically with a $\beta$-glucuronidase preparation 5,0 . The metabolite was identified by comparison with an authentic sample on thin film chromatograms. N-hydroxydiphenylamine, 2- hydroxydiphenylamine or unchanged diphenylamine could not be detected in the hydrolysed urines. The same metabolite was isolated after acid and enzymatic hydrolysis of bile following an intraperitoneal dose of diphenylamine. N-hydroxydiphenylamine rearranges and

1 This work forms part of a programme supported by Grant EF.258 of the National Institute of Health, U.S. Public Health Service, the National Health and Medical Research Council of Australia and the Council of the Australian Food Technologists Association.

2 R. T. Wriliams, Detoxication Mechanisms, 2nd Ed. (Chapman and Hall Ltd., London 1959), p. 428.

s E. Boyland and J. Booth, Annual Review of Pharmacology (Annual Reviews Inc., Palo Alto, California, U.S.A. 1962), p. 129.

4 H. Wirtand and A. RosezU, Ber, dtsch. chem. Ges. 45, 494 (1812).

5 R. I. Cox, Austr. J. Science 19, 202 (1957).

- R. I. Cox, Biochen. J. 71, 763 (1959). 